\title{
Médeiák diszkurzív keretben
}

\author{
Inge Stephan, Medea: Multimediale Karriere einer mythologischen Figur, \\ Köln - Weimar - Wien, Böhlau Verlag, 2006.
}

A 20. század utolsó évtizedeiben valóságos „Médeia-bumm” mozgatta meg a nyelvi és képi művészetek terepét Európában. A Médeia-mítosz adaptációiból válogatást közlő rangos antológia ${ }^{1}$ irodalomtudós-filozófus szerkesztője, Ludger Lütkehaus 300 feldolgozást tart számon a különféle médiumokban, de a Médeia-anyag meghatározó volt a tudományos beszédtérben is számos kutatási projekt, egyetemi kurzus és tanulmánykötet révén. A berlini germanista, gender-kutató, kultúra- és médiatudós Inge Stephan Médeia-monográfiája egyszerre része és összegző reflexiója is ennek a recepciós robbanásnak: tematikus lapszámunk számára ez a recepciós helyzet és teljesítmény teszi igazán érdekessé a könyvet, immár több mint tíz évvel a megjelenése után is. Szerzöje egyébként - ahogy a könyv elöszavában írja - maga is vezetett egyetemi kurzust a témában (Médeia - Mítoszok - Médiumok címmel, 1999-2000-ben), ahol a primer esztétikai tapasztalat szinkron nézőpontjából olvas(hat)ta együtt hallgatóival a kortárs színpad, film, irodalom és képzőmüvészet Médeia-adaptációit, érzékelve és tudatosítva azt a diszkurzív teret is, melybe a képi és nyelvi Médeia-szövegek megérkeztek. ${ }^{2}$ Ennek a sajátos recepciós helyzetnek a következménye lehet, hogy Inge Stephan nemcsak hagyományos fogadtatástörténetet ír (poetológiai, mediológiai, hermeneutikai olvasásmódszertanok alkalmazásával), hanem diskurzusanalitikai munkát is, ahol azokat a kultúrantropológiai kontextusokat világítja meg, melyek értelmezhetővé teszik a Médeia-mítosz 20. századi aktualitását és aktualizálhatóságát. Stephan úgy látja, hogy a 20. század végén abból magyarázható mind a Médeia-mítosz iránti rendkívüli érdeklődés, mind a női alkotók számának megsokszorozódása, mind pedig az adaptációk jellege (az át- és felülírások, sőt: szétírások ideologikus és poetológiai irányultságai), hogy a Médeia-mítosznak (fóként az Euripidés előtti alakváltozatainak)³ olyan implikátumai

\footnotetext{
${ }^{1}$ Mythos Medea: Texte von Euripides bis Christa Wolf, hg. Ludger LütKeHAus, Stuttgart, Reclam Verlag, 2007. ${ }^{2}$ Inge Stephan, Medea: Multimediale Karriere einer mythologischen Figur, Köln - Weimar - Wien, Böhlau Verlag, 2006, 6. (A monográfiából vett további idézetek, utalások oldalszámait a citátumok után, zárójelben adom meg. - B. E.)

${ }^{3}$ Az Euripidés előtti alakváltozat fogalma nem konkrét irodalmi feldolgozásokat jelöl, hanem egy virtuális Médeia-mitologémát, amely az antikvitás szöveghagyományában fellelhető utalásokból alakítható ki, $\mathrm{s}$ amely a klasszika-filológia Médeia-vitáiban meg is képződött. Inge Stephan Konrad SeELIGER (Ausführliches Lexikon der griechischen und römischen Mythologie, hg. Wilhelm H. Roscher, Leipzig, Teubner Verlag, 1894-1897, II, 2482-2515.), Albin LESKY (Realenzyklopädie der classischen Altertumswissenschaften, hg. August W. Pauly, Georg Wissowa, München, 1931, XXIX, 29-64.) és Margot Schmidt Lexicon Iconograficum Mythologiae Classicae, hg. Lilly KAHIL, Zürich, Artemis Verlag, 1992, VI, 386-398.) Médeia-
} 
vannak, melyek alkalmassá teszik arra, hogy bizonyos kortárs diskurzusok artikulációs médiumává váljon.

Stephan négy ilyen diskurzust vél elkülöníthetőnek:

1, a feminizmus és a gender diskurzusait, amelyek számára pozitív vagy negatív identifikációs minta (Identifikationsfigur) Médeia, akinek megöröklött történetei a nemi szerepek újraértésére inspiráló társadalmi kihívások kontextusaiban aktualizálódnak; 2, az erodálódó közösségi (a családi, az anyai) szerepmintázatok diskurzusait, amelyek a válságokon uralkodni tudó (és merö!) Médeia-aspektusban (Bewältigungsfigur) mutatják fel a mítosz kortársi érvényességét;

3, az idegenség diskurzusait, ahol a Médeia-narratívák a különféle kulturális (etnikai, nemi, vallási) másságokhoz kapcsolódó jelenkori projekciókat, félelmeket és vágyakat teszik artikulálhatóvá (Projektionsfigur);

4, az erőszak diskurzusait, amelyeknek reflexiós terében a vérbosszú és az emberáldozat archaikus praktikáinak szintjére „visszaeso"” Médeia figurája által lehet megszólaltatni az agresszió kultúrantropológiai dilemmáit (Reflexionsfigur). (4-5.)

Ezek a társadalmi konfliktusmezők Inge Stephan recepcióesztétikai olvasataiban is értelmezési keretként működnek, azt a horizontot jelentik, amelyen a mitológiai és a görög-latin irodalmi Médeia-szövegek rendkívüli variabilitást mutató át- és felülírásai (különösen a 20. századiak) olvashatók és rendszerezhetők. „Médeia mindig is több volt, mint textuális figura, [...] ám csak [...] a művészet technikai sokszorosíthatóságának korszakában vált olyan nemzetközi ikonná, amelyet mindig akkor idéztek meg, amikor a nemek viszonya, a családi viszonyrendszerek jövője, az idegen

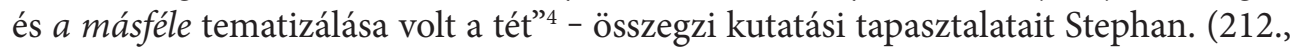
kiemelés tőlem)

A recepciós robbanás diszkurzív kontextusait jelentő kortárs társadalmi viták mellett, melyek, mondjuk így, korhangulatként töltötték be a nyilvánosság tereit, Stephan kijelöl egy konkrét filozófiai szöveget is a Médeia-mítosz anatómiájának és 20. századi sikertörténetének értelmezőjeként: Horkheimer és Adorno 1944-ben írt, de a kultúrpolitikai nyilvánosság terében majd csak az 1968-as diákmozgalmak révén szerepet játszó (igaz, a baloldali értelmiség körében ekkoriban kultikus szövegként használt) kritikafilozófiai munkáját, A felvilágosodás dialektikáját. (Dialektik der Aufklärung). Ez a választás igencsak meglepő, ha a 20. század 80-as, 90-es éveinek tudományos beszédtereiből magunk elé idézzük a humán tudományok rendkívül gazdag mítoszkritikai kínálatát. Főként a mítoszt antropológiai, poetológiai, filozófiai, vallástörténeti aspektusokból

szócikkeire hivatkozik, amelyek ráirányították a figyelmet a szóbeliségben feltételezhető Médeia-történetek sokszínűségére és változékonyságára, egyszersmind a Médeia-figura értelmező kánonját kijelölő és (azt egészen a 20. századig) meghatározó euripidési feldolgozás történetiségére. Christa Wolf 1997-ben írt eszszéjét idézve (Vom Kassandra zu Medea - Kasszandrától Médeiáig) Stephan azt tudja bemutatni, milyen felszabadító volt a klasszika-filológia tudományos diskurzusának ez az összetett Médeia-képe a 20. század 80-as, 90-es éveiben a nőírók számára. (9-12.)

${ }^{4}$ Amennyiben külön nem jelzem, az idegen nyelvü idézeteket a saját fordításomban közlöm. - B. E. 
újraértő kutatásoknak azt a korpuszát, mely gyakran vonta értelmezési körébe a Médeia-mítoszt, és választ keresett a Stephant foglalkoztató kérdésre is: mi magyarázza a mítoszok aktualitását a modernitás szekularizált, racionalizált és technikai kultúrájában?

Horkheimer és Adorno ma már inkább csak apokaliptikus látomásként olvasható esszégyüjteménye iránt Inge Stephan persze érzékeny lehetett az úgynevezett baloldali irodalomtudomány (linke Literaturwissenschaft) elkötelezettjeként is; fontosabb azonban, hogy a mü negatív dialektikája a Médeia-figurában (is) hagyományozott félelmetes antropológiai ambivalenciát - kultúra és barbárság, értelem és téboly paradox egységét -, valamint a téboly előtörésének mechanizmusát is megvilágíthatta számára. A mítosz és a modernitás viszonyát sajátos narratívaként megkonstruáló Dialektik szerint a természet fogalmi megismerése által a felvilágosodás (Aufklärung) ${ }^{5}$ lehetővé teszi a mítoszból való kiemelkedést. Azonban a mítosz átfordulása a racionalitásba csak az elidegenedés árán mehet végbe, aminek nyomában az embert új természetként igázza le az, amit maga fejlesztett ki a természet leigázására. Horkheimer és Adorno szerint ebben áll a civilizációs folyamat negatív dialektikája, a felvilágosodás visszatérése a mítoszba. ${ }^{6}$ Pontosabban az elfojtott mítosz barbár kitörése az ész hatalmából, ami azt jelenti, hogy - amint a Dialektik elemzésében Bielik-Robson írja - a „mítosz jelenléte a modernitásban jóval [...] ambivalensebb, mint az archaikus univerzumban: megnyilvánulása a felvilágosodás kultúrájában kifejezetten »unheimlich «, nyugtalanító”?

Alogika kérlelhetetlenségével felépített civilizációtörténeti víziót, melyet Horkheimer és Adorno modernitáskritikának szánt, s melynek sem téziseit, sem modalitását nem függetleníthetjük a szöveg genezisétől (a fasizmus és a háború okozta félelmektől, illetve a szerzők emigrációba kényszerülésétől), Inge Stephan a dekontextualizáció olvasásmódszertanával közelíti meg. Figyelemmel a Médeia-recepció metadiskurzusaiban jelentős szerepet játszó feminista értelmező narratívákra ${ }^{8}$ (s nem függetlenül a saját

\footnotetext{
${ }^{5}$ A szöveg szerzői számára a felvilágosodás nem az eszmetörténeti korszakfogalmat, hanem az ész hatalmát jelöli.

${ }^{6}$ Vö. Max Horkheimer, Theodor W. Adorno, A felvilágosodás dialektikája: Filozófiai töredékek, ford. Bayer József, Geréby György, Glavina Zsuzsa, Vörös T. Károly, Bp., Atlantisz, 1990, föként 19-62.

${ }^{7}$ Agata Bielik-Robson, Két Odüsszeia, avagy meditáció a remény hiányáról, ford. SeleAnu Magdaléna, Szombat, 2005.10.01. http://www.szombat.org/archivum/ket-odusszeia-avagy-meditacio-a-remenyhianyarol-1352771427_(Kiemelés az eredetiben.) (Letöltés ideje: 2017. augusztus 1.)

${ }^{8}$ Inge Stephan azonban kritikailag szemléli az irodalmi Médeia-adaptációk feminista értelmezés-hagyományát. Elfogadja ugyan, hogy már az euripidési adaptációt is bizonyos „gender-dramaturgia” (házassági konfliktus) szervezi, de úgy véli, hogy azt mégsem lehet „a görög patriarchátus feminista szubverziójaként olvasni”. (101.) Maga is a tragikus és/vagy örült szerelem narratíváinak jegyében, a „gender-trouble" (Judith Butler) szerelem-aspektusának nézőpontjából értelmez számos adaptációt (Ovidius bizonytalan datálású Epistulae Heroidumának Médeia-levelét [Hösnők levelei], Seneca Medea-drámáját [Kr. u. 62-65 között], Grillparzer Das goldene Vließ [Az aranygyapjú, 1822] trilógiájának Médeia-részét, Hans Henny Jahnn Medea-drámáját [1924-1926], Fridericke Mayröcker Medea und Jason [Médeia és Jason, 1954] című elbeszélését, Heiner Müller Médeia-pantomimjét [Medea-Spiel, 1974], Dea Loher Manhattani Médeiáját [Manhattan Medea, 1999]) (98-112.), ugyanakkor azt is bemutatja, hogy a nőmozgalmak második németországi hullámának erőterében a gender-aspektusú Médeia-adaptációk gyakran az agitatív szemléltető eszköz (Gebrauchstext) sze-
} 
kutatási profiltól) Stephan a gender studies perspektívájából olvassa és hasznosítja újra a Dialektik szövegét. Azokat a passzusokat állítja reflektorfénybe, amelyek a nők társadalmi elnyomásának legitimációs mechanizmusait tárják fel, s drámai képekben mutatják be, hogyan születik meg a nők feletti férfiuralom (és férfierőszak) legitimitásának ideológiája (és intézményrendszere) annak az ártatlannak tetsző metaforizációs aktusnak a nyomán, amelyben a civilizatórikus episztéméket (mítosz, logosz) a nemiség kódjaival látják el: vagyis a mítoszt és a természetet feminizálják, az észt és a civilizációt pedig maszkulinizálják. ${ }^{9}$ Hiszen, ha „a nő a természet képe, amelynek elnyomásában áll a civilizáció dicsősége", ${ }^{10}$ akkor a természet feletti uralom és a nő elnyomása elválaszthatatlanul összetartozik, s ebböl az elnyomásból a nő csak szörnyetegként tud kitörni (pontosabban előtörni). Ugyanakkor a természet és a nő metaforikus azonosítása a mítoszi episztémé terméke Horkheimer és Adorno szerint - erre vonatkozik alaptézisük másik fele: „már a mítosz is felvilágosodás." ${ }^{11}$ A Dialektik dialektikus modellje felülírja a kauzálist, nem határt von uralom és alávetettség, tettes és áldozat között, hanem megmutatja azok egymást teremtő, erősítő és aláaknázó összetartozását.

Inge Stephan úgy látja, hogy a Médeia-mitologéma ijesztő ambivalenciájának az adornói-horkheimeri civilizációtörténeti dialektika gender-aspektusa a kulcsa, ${ }^{12}$ és azt sugallja, hogy a különböző korok (esztétikák és ideológiák) interpretációinak különbségei is ehhez az ambivalenciához való viszonyulás eltéréseiből eredeztethetők. ${ }^{13}$ Ugyanis

repét töltötték be. (163.) Például az 1982-ben újra kiadott századelős feminista folyóirat, a Frauenbrevier für männerfeindliche Stunden (Női zsolozsmás könyv férfiellenes órákra, 1907) Médeiát az amazon-mitologéma jegyében aktualizálta, a (gyenge) férfitól független, harcos Penthesileiaként, akire nővérként tekinthettek (Identitifikationsfigur) a társadalmi, politikai és szexuális felszabadulásukért harcoló nők. (158.) Az alternatív La Communa, Dario Fo és Franca Rame Európa-szerte turnézó politikai színháza (a politikai eszméltetés céljával összeállított allegorikus színpadi jelenetsor $L a$ Medea címủ szekvenciájában) olyan Médeiát léptetett színpadra, aki „a feminista öntudatra ébredés fanfárjaként” (162.) szólítja meg nőtársait. Stephan ezért is idézi egyetértéssel Johannes R. Gascard-t (Medea-Morphosen: Eine mytho-psychohistorische Untersuchung zur Rolle des Mann-Weiblichen im Kulturprozess, Berlin, Duncker \& Humblot, 1993.), aki a korszak gendervitáinak elgondolkodtató krízistünetét is meglátja a 20. század végének Médeia-bummjában. (164.)

${ }^{9}$ Vö. Horkheimer, Adorno, i. m., főként 285-296.

${ }^{10}$ Uo., $290-291$.

${ }^{11}$ Uo., 16.

${ }^{12}$ Tagadhatatlan fogyatékossága a monográfiának, hogy szerzője számára a Dialektik gender-aspektusa és erőszakfelfogása nemcsak értelmező keret, hanem mesternarratíva is, amelyre allegorikusan vonatkoztatja a konkrét Médeia-adaptációkat. Többször visszatérő konklúziója (vagy épp kiindulópontja) egy-egy elemzésének, hogy az illető képi vagy irodalmi szöveg „hozzájárulás” (Beitrag) a Dialektik kérdésfelvetéseihez. Pasolini Médeia-filmje „bonyolult és zavarba ejtő hozzájárulás” (verworrener und verwirrender Beitrag) (215.), Ula Stöckl Der Schlaf der Vernunft (Ha alszik az ész) filmje „tisztánlátó hozzájárulás” (hellsichtiger Beitrag). (238.) Grillparzer dramatikus trilógiájában (Das goldene Vließ [Az aranygyapjú]) Médeia átváltozása charisból menáddá párhuzamot mutat azzal, ahogyan a Dialektik leírja, hogyan jelenik meg az elnyomott nő a megéra alakjában (55.); Heiner Müller Argonauták-trilógiájának civilizációkritikai és patriarchátuskritikai elemei pedig „világos egyezéseket” (deutliche Übereinstimmungen) mutatnak Walter Benjamin és a Dialektik történelemfelfogásával. (131.)

${ }^{13}$ Ugyancsak ennek következményeként értelmezi Stephan a női alkotók késői (jobbára csak a 20. század második felére datálható) bekapcsolódását a recepciós folyamatba. $(5,22,116,141-143$. 
a mítoszi történet ellentmondásos hősének (és tetteinek) a legsajátabb, ugyanakkor a legnehezebben dekódolható aspektusa - méghozzá nemcsak a keresztény Európa nőképeinek, hanem a nőiség antropológiailag megalapozott identitásformáinak nézöpontjából is - az, hogy Médeia nő. A figurájában testet öltő paradoxonok sorozatából (egyszerre gyógyító és pusztító varázsló, bátor és okos rétor, szenvedélyes és szenvedő szerető, oltalmazó anya és bosszúálló gyilkos, szolga és király, tettes és áldozat, isten és ember) a gyilkoló anya képe a legabszurdabb - ez a voltaképpeni unheimlich. Ennek a (bizonyos premisszák szerint) antropológiai nonszensznek a kivetüléseként, a vele való intellektuális és emocionális küzdelem lenyomataként tekinthetünk például arra a recepciótörténeti tényre, sugallja Stephan, hogy az adaptációk között a gyermekgyilkosság vonatkozásában a legnagyobb a szóródás. $(7-8,12,78,116,146-147$.

A kortárs interpretációk jelentős csoportja a felmentés valamiféle kódját keresi: nem ritka a gyilkosságok közvetett (közvetített vagy háttérben hagyott) megjelenítése, elhallgatása, áthelyezése, a gyilkosság átértelmezése, sőt: a gyilkosságok nélküli Médeia. Helga M. Novak Brief an Medea (Levél Médeiának, 1978) címü szövegének fiktív levélírója aljas rágalomnak nevezi a gyilkosságot és Euripidést vádolja, aki 40 ezüstöt fogadott el a korinthosiaktól a terjesztéséért. Ula Stöckl Der Schlaf der Vernunft (Ha alszik az ész) 1984-es filmjében (mely címével az El sueño de la razón címen híressé vált Goya-rézkarc [1799] ész/álom-felfogására utal) Dea csupán az álomban éli ki gyilkos indulatait és öli meg lányát és férjét; Ursula Haas Freispruch für Medea (Felmentés Médeiának, 1987) című regényében pedig abortusz formájában megy végbe a gyermekgyilkosság: Médeia elveteti a hütlen Iasónnal nemzett magzatát. A Médeia-aspektusokból csak a pozitívakat használja fel Christa Wolf a Medea. Stimmen (Médeia. Hangok, 1996) epikus Médeia-figurájához, akinek gyermekeit a brutalizálódott tömeg, fivérét Aiétés, hataloméhes apjuk öli meg; a mindenkit gyermekének fogadó nő alakjában Ljudmila Ulickaja pedig egyenesen egy ellen-Médeiát formál meg, akit inkább lehet az ősanyanarratívák, mint a Médeia-mitologéma felől olvasni (Médea és gyermekei, 1996).

Jelentős a száma azonban az újabb pszichiátriai/pszichológiai nő-narratívákkal (a Médeia-komplexus orvosi narratívája, a pusztító anyaság kórképe $)^{14}$ is párbeszédbe léptetett, egyszersmind a fúria-mitologéma hagyományterébe állított adaptációknak is, melyek időnként a gyilkosságok szadisztikus ábrázolásától sem riadnak vissza.

\footnotetext{
${ }^{14}$ A női, családi, anyai szerepmintázatok kortárs diskurzusai között, melyeket Stephan megidéz a Médeiaadaptációk és interpretációk kontextusaiként, kitüntetett hely jut a gyilkos anyákról szóló nyilvánossági vitáknak. A monográfia bevezető fejezetként (7-27.) tárgyalja az anya-Médeia feloldhatatlan dilemmáját (anyai szeretet és gyermekgyilkosság), hivatkozással jó néhány ekkor megjelent pszichiátriai, pszichológiai, társadalomlélektani monográfiára, amelyek a gyermekgyilkosság kriminalisztikai eseteit vizsgálva bontották meg az anyai szeretet közkeletü mítoszait (269.). Sőt, olyan ellentmondásos késztetésekre bukkantak az anyai ösztönéletben, melyeket a Médeia-mitologéma felől lehetett medikalizálni (Médeia-komplexus). Inge Stephan alighanem ezért is elemzi hosszabban Jules Dassin Médeia-filmjét (A Dream of Passion, 1977), melynek alapszituációja az, hogy egy Médeiát alakító színésznő a szerep megértésének érdekében felkeres a börtönben egy gyermekgyilkos anyát. A mozgóképi médium teljesítménye az, hogy egybeolvasztja a két Médeia arcát, s ezzel a Médeia-mitologéma legfőbb dilemmáját változtatja érzéki tapasztalattá. (226-232.)
} 
Elisabeth Langgässer Märkische Argonautenfahrt (Brandenburgi Argonauta-út, 1950) címü regényében Médeia a gonosz anya mitikus ősképét testesíti meg, egy szörnyeteg Magna Matert, aki elnyeli, akit és amit szült, és akire ezért ki is vetítődik mindenféle félelem. A festőművész Angela Hampel a bohóc, az állat és a nő ikonográfiai jegyeit keverve formál megdöbbentő Médeia-figurát (1985), aki „született gyilkosként” fogja rá a kést gyermekére. Dea Loher manhattani Médeiája (Manhattan Medea, 1999) a testvérgyilkosság traumatikus hatása alatt, de kétségbeesett elszántsággal öl újra és újra: végül fiát is belefojtja egy nagy müanyag zsákba, majd öngyilkos lesz - mindezt a színpad előterében.

A dialektikus értelmező modell perspektívájából azonban - ahogyan Stephan elképzeli a Dialektik hatása nyomán - nem az egynemüsítés ideológiai és poetológiai kódjai határoznák meg a Médeia-mitologéma transzformációit, hanem a számvetés azzal, hogy Médeia nem csak áldozat, aki mint alávetett és megalázott kitör a férfiuralom alól a bosszú által, hanem „tettes is, akinek cselekedeteiben $a z$ alávetett és megalázott - mint szörnyűség - visszatér". (143., kiemelés tőlem) Inge Stephan olvasatában Elfride Jelinek irtóztató Médeia-konfigurációja (Lust, 1992, Tandori Dezső fordításában magyarul Kéj címen jelent meg) látszik ilyennek, az egyszerre nimfomán és - a testén elkövetett szexuális erőszaksorozat következtében - frigid Gerti, aki action gratuite-indulatból, egyszersmind hidegvérü szakszerüséggel fojtja meg fiát egy reklámzacskóval, reprezentálva, hogy az erőszakspirál végzet is és bün is, amelyre nem az ítélet és nem a felmentés, hanem az elhallgatás lehet a válasz. (179-181. $)^{15}$

A kontextuális olvasás - legyen annak tárgya akár képi, akár textuális szöveg - nem ritkán jelent egyet allegorikus narratívák és értelemalakzatok létrehozásával, a vizsgált szöveg poetológiai és mediológiai aspektusainak mellőzésével: ez Inge Stephan diskurzus-applikációiban is tetten érhető. Főként a mester-narratívaként alkalmazott adornói-horkheimeri civilizációtörténeti esszé vonatkozásában mutatkozik ez a narratológiai, dramaturgiai, ikonográfiai nézőpontokat kikapcsoló értelemképzés. ${ }^{16}$

\footnotetext{
${ }^{15}$ A regény alany nélküli antigrammatikus zárómondata a rasten ige széles szemantikai körével (megszakít, pihen, megáll, elidőz, elgondolkodik stb. („Aber nun rastet eine Weile.” - „De még időz egy darabig.”) talán erre utal. Stephan Jelinek-elemzésének zárlata (véleményem szerint önellentmondásként) azonban az autonóm szubjektum felszámolódásaként olvassa a jelenetet. (181.)

${ }^{16}$ A 20. század végén kibontakozott (és felgyorsult) Médeia-recepció négy diskurzus által összefogott és elbeszélhetővé tett történetét Inge Stephan 15 fejezetre osztja; ebben a felosztásban részint a Médeia-anyag különféle aspektusai (anyaság, szerelem, családi kapcsolatrendszerek, nemiség, vágy és erőszak, idegenség) az irányadóak, részint a Médeia-adaptációk mediális különbségei (a zenei és a filmes adaptációk például külön fejezetbe kerültek). Azonban a 15 fejezet 15 önálló tanulmány is, vagy még inkább a szemléltetés és didaktizálás retorikáját alkalmazó egyetemi előadás. A monográfia értéke (s talán fogyatékossága is) a két módszertan, az erős és reflektált teoretikusság, illetve a didaktikusság összeházasítása. Aki lineárisan olvassa a könyvet és az egységesítő narratívát keresi benne, azt sok tematikus átfedés, frazeológiai ismétlés, ellentmondás fogja zavarba hozni. Az egyes tanulmányok olvasóit azonban lenyügözi az egyenként is hallatlanul összebogozott témanyaláb logikus szétszálazása, az elözetes tudásokat átmozgató új nézőpontok kijelölése. És talán a monográfia nem is ,,a nagy narratívát” elváró lineáris olvasásban mutatja meg erényeit (illetőleg tudományos relevanciáját), hanem az eset mint exemplum elbeszélése iránt fogékony befogadásban.
} 
Nem okvetlenül ennek kritikájaként (hiszen Inge Stephan monográfiájában - felülírva a teoretikus allegorézist - a gazdag szempontrendszerü, érzékeny és nagy megjelenítő erővel bíró müelemzéseké a föszerep) érdemes felidézni Hans-Thies Lehmann párhuzamos (szintén a németországi Médeia- és mítosz-bumm évtizedeiben született) Médeia-olvasatát, amelyre egyébként Stephan is hivatkozik. (143.) Annál inkább tanulságos lehet ez, mert a színháztudós Lehmann is Horkheimer és Adorno civilizációkritikai esszéinek kontextusában (jóllehet, azok mítoszelméleti felfogására figyelve) értelmezi újra a Médeia-mitologémát. ${ }^{17}$

Lehmann számára - aki a szubjektumképződés kontextusaként fogja fel az antik tragédia és színház diszkurzív terét - Médeia figurája a tragédia közegében kihordott (és reprezentált) szubjektummá válás folyamatának egy állomása: alakja metszéspont, hiszen egyszer szuverén döntéseket hozó individuum, máskor a mitikus sors, az istenek, a természet erőjátékának terepe. Emblematikus erővel mutatja fel ezt számára az euripidési dramatikus szövegváltozat zárlata, ahol Médeia elrepül a dráma és a színpad teréből azon a sárkányfogaton, melyet nagyapja, Hélios napisten küldött neki. Médeia visszatér a mítoszba halott gyermekeivel, a sárkányfogat visszaviszi őt abba a mitikus rendbe, melyből az Iasónnal való házassága révén egy rövid időre kivált: a „minden mérték felett megalázott asszony visszaváltozik a mitikus őserővé (Urgewalt)". ${ }^{18}$ Stephantól eltérően Hans-Thies Lehmann nem állítja fókuszba a mitologéma nemi aspektusait, hisz az asszonnyá válást inkább érti szubjektummá válásként, semmint egy nemi szerep elnyeréseként (amint a megcsalást pedig a szubjektivitáson esett sérelemként). Lényegesebb különbségnek látom ennél, hogy Lehmann nem pszichoanalitikus metaforikával (feltörés, kitörés) írja le a mitikusba való visszatérést (illetőleg a mitikus visszatérését), mint Stephan, hanem a metamorfózisra utaló szóval: verwandelt sich zurück - az átváltozott átváltozásaként értelmezve azt. A Médeia-történeteket ily módon az átváltozás-mitologéma felől olvasva két különnemű szimbolikus rend - a humán és a mitikus - találkozásának dinamikája ölt testet Médeiában: az ítéletet hozni képes, ezért morálisan és emocionálisan megítélhető (és elítélhetö) emberi szubjektumé és a mitikus gépezeté, melyhez nem lehet hozzáférni a humanitas kódrendszereivel.

\footnotetext{
${ }^{17}$ Hans-Thies Lenmann, Theater und Mythos: Die Konstitution des Subjekts im Diskurs der antiken Tragödie, Stuttgart, Metzler Verlag, 1991.

${ }^{18}$ Uo., 188. - Az Urgewalt egyszerre jelent őserőt és elementáris erőszakot.
} 